УДК $349.2 ; 349.3$

DOI https://doi.org/10.32844/2618-1258.2019.5-1.19

КЛИМЕНКО А.А.

\title{
НЕЛЕГАЛЬНЕ ПРАЦЕВЛАШТУВАННЯ В УКРАЇНІ: ЗАГАЛЬНА ХАРАКТЕРИСТИКА ТА СПЕЦИФІКА ПРАЦЕВЛАШТУВАННЯ ВНУТРІШНЬО ПЕРЕМІЩЕНИХ ОСІБ
}

\begin{abstract}
У цій статті було розглянуто досить актуальне явище «нелегальний ринок» або, як ще його називають, «тіньовий ринок праці». Було проаналізовано проблему тіньового ринку праці та перспективи проведення політики «детінізації», адже тіньовий ринок праці є гальмом для розвитку правової, соціальної та демократичної держави. Наведено фактори, які сприяють активному поширенню цього явища в нашій державі та висвітлено дані досліджень Міжнародної організації праці щодо кількості осіб, які нелегально працевлаштовані. Також було наведено практичний приклад того, як можна боротися із тіньовим ринком: прикладом може слугувати Харківська область, яка розробила власні механізми та важелі впливу на свідомість людей щодо припинення нелегального ринку праці. Стаття висвітлює ті проблеми, які $є$ в нашій державі стосовно законного регулювання трудових правовідносин. Було окреслено найбільш ефективні методи боротьби з процесом нелегального працевлаштування та висвітлено основні дієві напрями держави стосовно тіньового ринку праці відповідно до Розпорядження КМУ «Про заходи, спрямовані на детінізацію відносин у сфері зайнятості населення». Яскравим прикладом проблеми легального працевлаштування було зазначено проблеми внутрішньо переміщених осіб як однієї з уразливих груп населення України. Зроблено акцент на виникненні трудових правовідносин у ВПО після розірвання трудового договору з попереднім роботодавцем та описано процедуру розірвання. У висновках зазначено рекомендації внесення змін до національного законодавства. Зазначено, що все має бути врегульовано законодавчо, особливо трудові правовідносини, від яких залежить соціальне становище не лише окремої особи, а й всієї держави загалом і результат можна очікувати лише при взаємодії не лише органів державної влади, а й органів місцевого самоврядування, які контролюють ситуацію на місцях та вживають певних заходів для мінімізації тіньового ринку праці.
\end{abstract}

Ключові слова: тіньовий ринок праці, статистичні дані, напрямки розвитку, Стратегія економічного зростання, внутрішньо переміщені особи.

In this article the actual phenomenon was considered "illegal market" or it is named as "shadow labor - market". The problem of shadow labor - market and prospect of realization of politics of "unshadowing" was analysed, in fact a shadow labor - market is a brake for development of the legal, social, and democratic state. Factors that assist active distribution of this phenomenon in our state are brought and data of researchers of International organization of labor are reflected in relation to the amount of people that are illegally employed are brought. A practical example of that how it is possible to contest with a shadow market was also made, example of Harkiv that worked out own mechanisms and levels of influence on consciousness of people in relation to stop illegal labor - market. This article lights up those problems that now exist in our state in relation to the legal adjusting of labor legal relationships. The most effective methods of fight were outlined against the process of illegal employment and basic effective directions of the state are reflected in relation to shadow labor - market in accordance with Order of High Ministry of Ukraine "About the events sent to unshadowing of relations in the field of employment of population". By the example of problem of legal employment the problems of the internally displaced people were marked, as one of vulnerable groups of population in Ukraine. An accent is done on the origin of labor legal relationships of

(С) КЛИМЕНКО А.А. - студентка міжнародно-правового факультету (Національний юридичний університет імені Ярослава Мудрого) 
internally displaced people after dissolution of labor contract with a previous employer and procedure of dissolution is described. In conclusions reccomendations of making alteration are marked to the national legislation. It is marked, that all must be well - regulated legislatively, especially labor legal relationships, on that social position of not only individual but also all state depends on the whole and result, it is expected of cooperation not only state authorities but also organs of local self - government that controls a situation on places and use events of minimization shadow labor - market.

Key words: Shadow labor-market, statistical data, directions of development, Strategy of the economy growing, internally displaced people.

Вступ. Нині ситуація в економічному плані в Україні є вельми скрутною, що спричиняє низку проблем і в трудовій галузі, і в культурній тощо. Економіка $є$ тим ковпаком, який зумовлює виникнення негативних наслідків у трудових відносинах у нашій країні. Однією з глобальних, на мою думку, проблем є нелегальне працевлаштування або, як ще називають, тінізація ринку праці. I тому в умовах тотальної економічної кризи, в якій опинилась Україна, нелегальна зайнятість населення $є$ актуальною проблемою на рівні із безробіттям. Що ж стосується внутрішньо переміщених осіб, то це доволі актуально і нині, хоч проблема виникла 6 років тому. Однак проблема працевлаштування цієї категорії осіб досі є.

Постановка завдання. Завданням цієї роботи є дослідження факторів, які впливають на продовження процесу тінізації ринку праці, методи боротьби, які використовують у міжнародному просторі, та оцінка законодавчого регулювання цього питання з боку органів державної влади, проблеми, які виникають при працевлаштуванні внутрішньо переміщених осіб.

Результати дослідження. Як вже було зазначено, нелегальне працевлаштування є частиною тіньової економіки. Нелегальне працевлаштування являє собою неформалізовані трудові відносини між роботодавцем та працівником, недотримання роботодавцем положень законодавства щодо оплати праці, укладення трудового договору та інше.

Нелегальний ринок праці є глобальною проблемою у багатьох країнах, однак все різниться за масштабами проблеми та заходів мінімізації ії розмірів за допомогою законодавчого врегулювання. За даними МОП, приблизно 1,8 млрд осіб задіяні в нелегальному ринку праці. В Україні, за даними Державної статистичної служби за 2016 р., було зафіксовано 4 млн осіб у сфері нелегальної зайнятості, а в 2018 р. Міністерством соціальної політики було зазначено вже 8 млн осіб. Таким чином, щороку кількість таких осіб не зменшується, а лише збільшується. Постає питання: яким чином зменшити потік осіб із легального працевлаштування до нелегального і як ліквідувати фактори, що спричиняють тіньовий ринок праці. Втім, зрозуміло, що повністю викоренити цю проблему неможливо, як це показано на прикладі багатьох наших країн-сусідів.

Перш за все, для того щоб зрозуміти, як реалізувати політику щодо мінімізації тіньового ринку праці та які заходи необхідно впровадити, треба виокремити ті фактори, які зумовлюють породження цього несприятливого процесу. Досить багато науковців досліджували цю тему та мають власні думки з приводу цього питання.

Отже, виділяють такі фактори:

1) нестабільне податкове законодавство та непідйомні часом податкові внески, які громадяни мають сплачувати до Пенсійного Фонду, до Фонду соціального страхування та інше;

2) наболілим питанням і водночас фактором впливу є низький рівень заробітної плати. Цю проблему не можуть врегулювати ані попередня Верховна Рада України та Кабінет Міністрів, ані чинна ВРУ та Кабінет Міністрів України. Станом на 2020 р. мінімальний розмір заробітної плати становить 4723 гривні. I, як ми бачимо, в сучасних реаліях людині не вистачає цієї суми для життя. Таким чином, людина просто вимушена працювати на тіньовому ринку праці, щоб забезпечити себе та свою родину, а не офіційно за трудовим договором;

3) низький рівень надання освітніх, медичних послуг. Це відбувається через низьку заробітну плату, оскільки і лікарі, і вчителі отримують невисокі зарплати, i тому ці послуги надаються відповідно до цих показників;

4) відсутність реалізації задекларованих механізмів. Наш Уряд наче розробляє програми проведення політики щодо детінізації ринку праці, однак це все на папері, а дієвих механізмів реалізації, на жаль, не передбачено. Також на це великий вплив справляє корумпованість державних службовців, оскільки їхня мета спрямована не на задоволення загальнонаціонального інтересу, а на забезпечення приватного чи корпоративного. Доки органи законодавчої та виконавчої влади не розпочнуть масштабно діяти, тінізація ринку праці буде лише надалі процвітати. 
Це основні фактори, хоча виокремлюють й інші.

Розглянемо ситуацію тінізації ринку праці на прикладі Харківської області. Як відомо, повноваження щодо контролю ринку праці покладено на Державну службу України 3 питань праці. У Харківській області цим керує Головне управління державної праці Харківської області. Детінізація ринку праці є нині важливим напрямом економіки України, адже лише за таких умов можна значно підвищити рівень життя населення. Станом на 2019 р. загалом у Харківській області проживало 2685000 жителів, із них 10\% працюють на тіньовому ринку. Що ж сприяло такому низькому відсотку? Керівник Головного Управління державної праці в Харківській області зазначив, що головним методом, який вони використовували, був метод роз'яснювальної роботи. Та разом із тим Головне управління почало застосовувати такі каральні заходи, як штрафні санкції. На думку самого керівника, штрафи $є$ найбільш дієвим механізмом детінізації ринку праці. Це і зробило Харківську область однією з передових областей, які зменшили відсоток нелегальної зайнятості та цим самим підвищили розвиток області та обласного центру. Які ще методи використовували під час реалізації політики детінізації? Дієвими методами були поширення в усіх публічних місцях плакатів, буклетів, демонстрація відеороликів про те, що детінізація $\epsilon$ запорукою стабільності економіки, підвищення заробітних плат, соціальних виплат, зменшення податків та багато іншого. І результат свідчить, що це спрацювало. Таким чином, рекомендується іншим областям задіяти в проведенні цієї політики зазначені методи впливу. Ця політика була проведена в межах Розпорядження Кабінету Міністрів України «Про заходи, спрямовані на детінізацію відносин у сфері зайнятості населення» від 05.09.2018 р. На той час Уряд, очолюваний В. Гройсманом, виокремив 7 напрямів реалізації підвищення економічного стану країни через приведення в порядок ринок праці. Цими напрямами $є$ :

1) створення нових робочих місць;

2) стимулювання розвитку підприємництва та самозайнятості;

3) запровадження гідних умов праці;

4) професійне навчання громадян;

5) сприяння зайнятості молоді;

6) розвиток послуг на ринку праці;

7) механізми контролю трудової міграції.

На думку Уряду, це сприятиме виведенню з тіні ринку праці, наблизить країну до європейських стандартів та зробить життя громадян кращим. Однак, як було вже зазначено, механізми реалізації цих окреслених напрямів не були запроваджені так, як це було у Харківській області. Своїм розпорядженням Кабінет Міністрів України лише окреслив повноваження органів місцевого самоврядування щодо запровадження ефективних методів для боротьби із цим негативним процесом.

1) Державній службі з питань праці, Державній фіскальній службі, Пенсійному фонду, Національній поліції, іншим центральним органам виконавчої влади за участю органів місцевого самоврядування провести в установленому порядку комплексні заходи, спрямовані на детінізацію зайнятості та доходів населення;

2) Міністерствам, іншим центральним органам виконавчої влади переглянути власні нормативно-правові акти та внести до них зміни з метою посилення контролю за оформленням трудових відносин із найманими працівниками.

Щодо ситуації тіньового ринку праці в Свропейському Союзі, то в 2010 р. була прийнята Стратегія економічного зростання та зайнятості Європейського Союзу «Європа 2020». Ії ціллю $\epsilon$ підвищення легальної зайнятості населення ЄС до 75\%. У 2014 р. була прийнята Резолюція Свропарламенту «Ефективні інспекції з питань праці як стратегія покращення умов зайнятості в Європі». Що стосується напрямів, необхідних для детінізації, то вони перекликаються з напрямами, які розробив Уряд в 2018 р. Однак країнами-членами було розроблено додаткові, такі як: боротьба з корупцією, відмиванням коштів, спрямування політики на викорінення кримінального бізнесу та багато інших.

На жаль, нелегальне працевлаштування лише набирає обертів у сучасних реаліях нашої держави. Найбільша кількість людей за статистикою намагається нелегально працевлаштуватися серед уразливих груп населення. До таких груп ми зараховуємо молодь, вагітних жінок, інвалідів, внутрішньо переміщених осіб. За показниками дослідження міжнародних організацій та вітчизняних наукових досліджень було встановлено, що внутрішньо переміщені особи через низку факторів просто вимушені нелегально працевлаштовуватись. Отже, розглянемо фактори, які заважають ВПО легально працевлаштуватись із правової точки зору. 
Взагалі термін «внутрішньо переміщена особа» став активно використовуватися після трагічних подій 2014 р. в нашій країні. У 2015 р. було прийнято ЗУ «Про забезпечення прав і свобод внутрішньо переміщених осіб», який мав би встановити правові норми, які дозволили б цій категорії осіб почувати себе захищеними та рівними серед інших. Однак на практиці ВПО почали стикатися з низкою проблем. Хоча вимушені переселенці і мали закріплене право на працевлаштування, механізму реалізації, на жаль, не було передбачено. Глобальна проблема, з якою почали стикатися ВПО і нині вона $\epsilon,-$ це легальне працевлаштування. Відповідно до ЗУ «Про забезпечення прав і свобод внутрішньо переміщених осіб», ст. 7 надає право цій категорії осіб на пенсійне забезпечення, трудове працевлаштування та отримання інших соціальних виплат. Однак тут і виникає проблема, що тягне за собою збільшення кількості осіб, зайнятих нелегально.

Згідно із законодавством України для легального працевлаштування внутрішньо переміщених осіб їм необхідно розірвати трудовий договір із попереднім роботодавцем. Втім, на цьому шляху виникають перепони, за яких особи не можуть розірвати трудовий договір та зробити відповідний запис у своїй трудовій книжці, адже трудова книжка $є$ тим самим доказом того, що особа працює легально за трудовим договором або контрактом. Під час працевлаштування роботодавець не має права брати на роботу працівника, який перебуває у трудових відносинах 3 іншим роботодавцем і це зафіксовано на законних підставах у трудовій книжці. Законом встановлено, що у разі виникнення такої ситуації вимушений переселенець може відправити заяву до колишнього роботодавця з рекомендованим листом. Якщо цього зробити неможливо, то все вирішується у судовому порядку. Тоді рішення суду є підставою для прийняття на роботу роботодавцем. На жаль, дедалі частіше трапляються випадки, коли роботодавці одразу відмовляють вимушеним переселенцям у роботі, тим самим порушуючи право цієї особи на працевлаштування та вільний вибір роботи, також є випадки безпідставної відмови у прийнятті. Порушується одночасно ст. 43 КУ (кожна особа має право на працю) та ст. 5 КЗпП щодо гарантій забезпечення громадянам права на працю.

Цей фактор є найбільш та типовим, що зумовлює працевлаштування нелегально внутрішньо переміщених осіб. За соціологічними даними, серед внутрішньо переміщених осіб є наймані працівники, роботодавці, які самостійно наймають, та безробітні. Допоміжним фактором, що сприяє поширенню тіньового ринку праці для внутрішньо переміщених осіб, $є$ низька заробітна плата. Досить часто роботодавці пропонують роботу для вимушених переселенців із низькою заробітною платою, спираючись на відсутність досвіду, професійних навичок та інше.

Зневірившись через такі умови трудових відносин, внутрішньо переміщені особи просто не знають, як забезпечити себе та свою родину, маючи лише якісь мінімальні соціальні виплати: або пенсійне забезпечення, або соціальні пільги та інше. I єдиним виходом є нелегальне працевлаштування. Роботодавець бере на роботу вимушеного переселенця без зайвих ризиків для себе, не укладаючи трудового договору, що є порушенням законодавства, виплачує заробітну плату в так званому «конверті» особі. При цьому працівник не отримує ніяких відповідних записів до трудової книжки і $є$ абсолютно не захищеним, і в разі чого він не може захистити свої права в судовому порядку. Це стосується заробітної плати, матеріальної відповідальності у разі пошкодження майна роботодавця, охорони праці, визначення часу відпочинку, відпустки, унормованого робочого дня. Також це і відсутність трудового розпорядку, коли, уклавши трудовий договір, особа точно знає умови праці, а без трудового розпорядку працівник позбавлений такого права. У разі будь-якого порушення прав працівника роботодавцем працівник не зможе опиратися на статті КЗпП для захисту своїх прав. Таким чином, на мою думку, необхідно запровадити механізми легального працевлаштування внутрішньо переміщених осіб, закріпивши це відповідним способом у законодавстві України, як це зроблено в більшості європейських країн.

Висновки. Отже, підсумовуючи все вище наведене, варто зазначити, що наша країна не розробила на загальнонаціональному рівні дієвих механізмів боротьби з розквітаючим тіньовим ринком праці. Завданням органів державної влади та органів місцевого самоврядування $\epsilon$ чітке донесення до громадян про переваги виходу з тіні i, насамперед, забезпечити підтримку своїм громадянам. Внутрішньо переміщені особи не мають бути винятком, держава має докласти максимум зусиль, щоб подолати проблеми працевлаштування вимушених переселенців та покращити в рази їхнє життя. Я вважаю, що це є результатом плідної співпраці всіх органів публічної влади. Тільки законними методами ми зможемо досягти зростання економіки через детінізацію ринку праці, що дасть колосальні реальні доходи всім громадянам. 


\section{Список використаних джерел:}

1. Системні вади ринку праці України та пріоритети його реформування : аналіт. доп. / О. Пищуліна, О. Коваль, О. Кочеміровська. Київ : НІСД, 2010. 72 с.

2. Грішнова О.А. Економіка праці та соціально-трудові відносини [Текст] : підручник. Київ : Знання, 2004. 536 с.

3. Реформування соціальної політики в Україні: проблеми та перспективи. Навчальнонаукове видання / За загальною редакцією В.А. Скуратівського, В.П. Трощинського. Київ-Львів, $2012.367 \mathrm{c}$.

4. Харазішвілі Ю.М. Методичний підхід до оцінювання тіньової зайнятості в Україні / Ю.М. Харазішвілі, Н.М. Дмитренко. Економіка України. 2010. № 12. С. 16-28.

5. Про забезпечення прав і свобод внутрішньо переміщених осіб : Закон України від 20.10.2014 p. № 1706-VII. URL: http://zakon5. rada.gov.ua/laws/show/1706-18

6. Зенін А.П. Особливості захисту постраждалих внаслідок надзвичайних ситуацій. Актуальні питання удосконалення законодавства про праџю та соиіальне забезпечення : тези доповідей та наук. повідомл. учасників VII Міжнар. наук.-практ. конференції, м. Харків, 29 верес. 2017 р. / за ред. В.В. Жернакова. Харків : Право, 2017. С. 135-141.

7. Краус Н.М. Тіньова зайнятість і офіційне безробіття на ринку праці: світовий досвід і українські реалії / Н.М. Краус, С.Г. Самойленко. Науковий вісник Полтавського ун-ту економіки і торгівлі. Сер. : Екон. науки. 2014. № 1. С. 64-71.

8. Інститути зайнятості та безробіття: сучасні тенденції та виклики для України : наук. доп. / [В.М. Геєць, А.А. Гриценко, В.В. Близнюк та ін.]; за ред. В.М. Гейця, А.А. Гриценка; НАН України, ДУ «Ін-т екон. та прогнозув.». Київ, 2013. 248 с.

9. Гнучкість та захищеність на ринку праці. Досвід України : монографія / Е.М. Лібанова, О.В. Макарова. Київ : Ін-т демографії та соц. досліджень ім. М.В. Птухи НАН України, 2007. $495 \mathrm{c}$.

10. Лібанова Е. Ринок праці та соціальний захист: навч. посіб. із соц. політики / Е. Лібанова, О. Палій. Київ : Вид-во Соломії Павличко «Основи», 2004. 491 с. 